\title{
Morphological and Molecular Description of a New Species of Myxobolus (Myxosporea: Myxobolidae) Infecting Planiliza Macrolepis (Smith, 1846) From India
}

MARY SONIYA CORREYA ( $\nabla$ ronysony29@gmail.com )

Central Marine Fisheries Research Institute

Vijayagopal P.

Central Marine Fisheries Research Institute

Sanil N.K.

Central Marine Fisheries Research Institute

\section{Original Article}

Keywords: Myxobolus, myxospore, gills, plasmodia, molecular phylogeny, mullet, Cochin backwaters

Posted Date: February 5th, 2021

DOI: https://doi.org/10.21203/rs.3.rs-174039/v1

License: @ (i) This work is licensed under a Creative Commons Attribution 4.0 International License. Read Full License

Version of Record: A version of this preprint was published at Journal of Parasitic Diseases on March 19th, 2021. See the published version at https://doi.org/10.1007/s12639-021-01376-z. 


\section{Abstract}

The present paper describes a novel species of Myxobolus parasitizing the gill filaments of the largescale mullet, Planiliza macrolepis from Cochin backwaters, Kerala, India. The parasite develops in the gill filaments; plasmodia elongated, milky white, measured $1.37-2.18$ (1.78 \pm $0.35) \mathrm{mm} \times 0.07-0.12(0.10 \pm 0.02) \mathrm{mm}$ in size. Mature myxospores ovoid in valvular view, biconvex in sutural view with smooth shell valves and measured $6.24-7.02(6.63 \pm 0.23) \times 5.01-6.18(5.68 \pm 0.25) \mu \mathrm{m}$ in size. Polar capsules equal, oval with pointed anterior ends, $3.07-$ $3.58(3.33 \pm 0.12) \times 1.68-2.42(2.09 \pm 0.18) \mu \mathrm{m}$ in size. Polar filaments with 4 coils, measured $29.61 \pm 4.75 \mu \mathrm{m}$ in length when extruded. Sporoplasm binucleate with a rudimentary nucleus and a vacuole. A comparison with related Myxobolus species revealed significant morphological \& morphometric differences. In BLASTN and genetic distance analysis, the present parasite showed high divergence with other myxosporean sequences, indicating its molecular uniqueness. In Maximum Likelihood and Bayesian Interference analysis, the present species stands out with $M$. ramadus as sister branch within the Myxobolus clade. In infected gill filaments, the plasmodia caused swelling/deformation, compression of lamellae and reduction in respiratory surface area. Three of 222 P. macrolepis screened were infected, indicating a prevalence of $1.3 \%$. Considering the morphological, morphometric, molecular and phylogenetic differences with the previously described species of myxosporeans, along with the dissimilarities in host and geographical locations, the present parasite is treated as a new species and the name Myxobolus cochinensis $\mathrm{n}$. sp. is proposed.

\section{Introduction}

Myxosporeans are a diverse, exclusively microscopic, group of metazoan parasites belonging to the phylum Cnidaria. They mainly parasitize fishes and sometimes reptiles, amphibians and even higher animals, and have a complex life cycle that alternates between vertebrate (fish) and invertebrate (annelid) hosts (Wolf and Markiw 1984). Many myxosporeans are known to cause reduced growth and productivity, and even serious mortalities and economic losses in farmed fish worldwide (Abidi et al. 2015).

The genus Myxobolus Bütschli, 1882, the largest myxosporean genus, contributes to almost one-third of the myxosporean species reported so far (Eiras et al. 2014; Chandran et al. 2019). Eiras et al (2014) have compiled 905 nominal species of Myxobolus parasitizing various fishes, and till date 80 more species have been added to this list. Kaur \& Singh (2012) have reported 131 species of Myxobolus from Indian waters and since then 33 species have been added to this list. The genus Myxobolus is characterized by bivalvular myxospores which are ellipsoidal to ovoid or rounded in valvular view and biconvex in sutural view; with smooth shell valves and two pyriform, sometimes unequal polar capsules and binucleate sporoplasm, often with an iodinophilous vacuole. They are histozoic in nature, infecting various tissues as intercellular or sometimes intracellular cysts (Lom \& Dykova 2006).

Mullets are euryhaline fishes belonging to the family Mugilidae, inhabiting the coastal, temperate and tropical waters and have a worldwide distribution. Mullets are a preferred species in many parts of the world and many of them are considered potential candidates for aquaculture. Thirteen species of grey mullets have been reported from Indian waters, of which eight are commercially important (Luther 1973). The largescale mullet, Planiliza macrolepis Smith 1846 inhabits the shallow, brackish and coastal waters along the southwest coast of India and commands high market value. Parasitological studies carried out in mullets indicate that they are infected with large number of parasites, especially myxosporeans (Özer et al. 2016). Yurakhno \& Ovcharenko (2014) have reported 36 species of myxosporeans representing eight genera infecting Mugil cephalus, of which 21 belonged to the genus Myxobolus. World over, 51 species of Myxobolus have been reported from mullets, of which, 22 were found infecting the gills (Yurakhno \& Ovcharenko 2014; Marcotegui \& Martorelli 2017; Cardim et al. 2018; Rocha et al. 2019). Eleven species of Myxobolus, M. narasii (Narasimhamurti 1970), M. lizae, M. macrolepi and $M$. sphaeralis (Narasimhamurti \& Kalavati 1979), M. mugcephalus (Narasimhamurti et al. 1980), M. anili (Sarkar 1989), M. bankimi (Sarkar 1999), M. mugilii (Haldar et al. 1996) and M. goensis (Eiras \& D'souza 2004) have been reported infecting mullets from India. The present study describes a new species of Myxobolus infecting the gill filaments of $P$. macrolepis from Cochin backwaters, Kerala, India.

\section{Materials And Methods}

\section{Fish sampling}

Two hundred and twenty-two $P$. macrolepis were collected from Cochin backwaters $\left(9.9312^{\circ} \mathrm{N}, 76.2673^{\circ} \mathrm{E}\right)$ using Chinese nets/gill nets from October 2017 to September 2019. The fish ranged from $7.5-21.4 \mathrm{~cm}$ in length and $10-120 \mathrm{~g}$ in weight. The collected fish were brought live to the laboratory and were either examined immediately or maintained in tanks and studied at convenience. The fish were killed by neural pithing and the external surface was examined under a Nikon SMZ1000 stereozoom microscope (Nikon, Japan). The fish were dissected following standard necropsy procedures and their internal organs were separated and examined in detail for the presence of parasites. The gills were transferred to a cavity block with $0.75 \%$ saline and after removing the excess mucus, the gill filaments were examined in detail. Cysts were transferred to a slide, ruptured using a fine needle and examined under a Nikon Eclipse 80i microscope 
(Nikon, Japan). A few infected gill filaments were preserved in 95\% ethanol for molecular analysis, while mature myxospores released from ruptured cysts were used for preparing Giemsa-stained permanent smears.

\section{Morphology and morphometry}

Fresh myxospores were studied in detail using a Nomarski Differential Interference Contrast (DIC) objective at $\times 100$ magnification and photographed using a Nikon DS-Fi1c camera (Nikon, Japan). Myxospores $(n=30)$ were measured with the help of Nikon-Elements BR software, as suggested by Lom and Arthur (1989). Nikon Y-IDT drawing tube (Nikon, Japan) was used to make line drawings. Measurements are given in micrometres $(\mu \mathrm{m})$ as range followed by mean \pm standard deviation in parentheses.

\section{Histology}

Infected tissue samples were preserved overnight in 10\% NBF, and processed for histology as per standard procedures. Using a microtome (Leica, Wetzlar, Germany), $5 \mu \mathrm{m}$ thick sections were taken, stained with haematoxylin and eosin and photomicrographs were taken at various magnifications (Miller, 2012).

\section{Molecular analysis}

Genomic DNA was extracted from ethanol-fixed plasmodium on gill filaments using a Multi-Sample DNA Purification Kit (HiPurA $\left.{ }^{\text {Tm}}\right)$. Briefly, plasmodia were lysed in lysis buffer and Proteinase K, DNA was captured on to a membrane, washed with ethanol, eluted in nuclease free water and kept at $-20^{\circ} \mathrm{C}$ until further use. A small fragment of the SSU rDNA was amplified by nested PCR. The first round of amplification was performed using the primers, ERIB1 (5'-ACCTGGTTGATCCTGCCAG-3') and ERIB10 (5'-CTTCCGCAGGTTCACCTACGG-3') (Barta et al. 1997) followed by a second round using ERIB1 - ACT1R (5'-AATTTCACCTCTCGCTGCCA-3') (Barta et al. 1997; Hallet \& Diamant, 2001) and Myxgen4F (5'-GTGCCTTGAATAAATCAGAG-3') - ERIB10 (Barta et al. 1997; Diamant et al. 2004) primers. PCR was performed in $30 \mu$ total reaction volume containing $15 \mu$ l Dream Taq Green PCR Master Mix 2X (Thermo Scientific, USA), $12 \mu$ l nuclease-free water, $0.6 \mu$ l of each primer, $1.8 \mu \mathrm{l}$ template DNA. PCR was carried out in a ProFlex PCR system (Applied Biosystems, USA) with an initial denaturation at $95^{\circ} \mathrm{C}$ for $5 \mathrm{~min}$, followed by $35 \mathrm{cycles}$ of $94^{\circ} \mathrm{C}$ for $60 \mathrm{~s}, 56^{\circ} \mathrm{C}$ for $60 \mathrm{~s}$ and $72^{\circ} \mathrm{C}$ for $2 \mathrm{~min}$ and a final elongation at $72^{\circ} \mathrm{C}$ for 10 minutes for first round of amplification and the second round was performed with an initial denaturation at $95^{\circ} \mathrm{C}$ for $3 \mathrm{~min} / 5 \mathrm{~min}$, followed by $35 \mathrm{cycles}$ of $94^{\circ} \mathrm{C}$ for $60 \mathrm{~s}, 50^{\circ} \mathrm{C}$ for $2 \mathrm{~min} / 56^{\circ} \mathrm{C}$ for $60 \mathrm{~s}$ and $72^{\circ} \mathrm{C}$ for $3 \mathrm{~min} / 1.30 \mathrm{~min}$ and a final elongation at $72^{\circ} \mathrm{C}$ for $10 / 5$ minutes. PCR products were resolved on $1.5 \%$ agarose gel in Tris EDTA buffer and stained with ethidium bromide. The positive amplicons were removed, purified using a HiPurA ${ }^{\text {TM }}$ Quick Gel Purification Kit (HIMEDIA, India) and Sanger sequencing carried out using ERIB1, ACT1R, ERIB10 and MYXGEN4F primers by a commercial company.

\section{Phylogenetic analysis}

Partial sequences of the three isolates (approximately 920bp, $776 \mathrm{bp}$ and 863bp generated using ERIB1-ACT1R, and 1098bp, 1162bp, and 1161bp generated using MYXGEN4F-ERIB10 respectively) were assembled from two overlapping fragments, edited using BioEdit V7.2.5 (Hall 1999), and the resulting sequences with 1902bp, 1955bp and 1908bp length deposited in NCBI GenBank (Accession numbers: MT305662, MT305663 and MT305666). BLASTN analysis of the isolates was performed in NCBI and phylogenetic analysis carried out using partial 18S SSU rDNA sequences of 15 species of Myxobolus selected based on the similarity scores, and 13 other representative myxosporeans downloaded from GenBank. Sequences were aligned using Clustal W module in MEGA 7 (Kumar et al. 2016). Genetic distance analysis was carried out using P-distance model. Best-fit model for phylogenetic analysis appeared to be GTR+I+G based on Akaike's information criterion. Maximum Likelihood (ML) tree was constructed with the sequence of Buddenbrockia plumatellae (Accession no. KJ741235) as out group with rapid bootstrap method using a random starting tree and $1000 \mathrm{ML}$ bootstrap replicates. Bayesian Inference (BI) was conducted in MrBayes, version 3.1.2 (Ronquist \& Huelsenbeck 2003) using Markov Chain Monte Carlo searches of two simultaneous runs of four chains of $20,00,000$ generations, with every $1000^{\text {th }}$ tree being sampled. The first $25 \%$ trees were discarded as burn-in, and the posterior probability of each node was calculated for the remaining trees. The resulting $\mathrm{ML}$ and $\mathrm{BI}$ trees were edited and annotated in Figtree v1.4.0 (Rambaut 2008) and Adobe Photoshop (Adobe Systems Inc. San Jose, CA) respectively.

\section{Results}

Three of 222 P. macrolepis screened harboured cysts of a species of Myxobolus indicating a prevalence of 1.3\%. Elongated, milky-white plasmodia were found developing within the gill filaments (Fig. 1 a); measured $1.37-2.18(1.78 \pm 0.4)$ mm in length and 0.07-0.12 (0.10 \pm 0.02) $\mathrm{mm}$ in width.

\section{Morphological description ofmyxospores}


Mature myxospores were bivalvular with thick shell valves and a prominent suture; ovoid in valvular view and biconvex in sutural view; with a rounded anterior end and slightly narrow posterior end; measured $6.24-7.02(6.63 \pm 0.23) \mu \mathrm{m}$ in length and $5.01-6.18$ (5.68 \pm 0.25$) \mu \mathrm{m}$ in width $(n=30)$ (Fig. 1 b,c,f). Polar capsules equal, oval in shape with pointed anterior ends and occupied the anterior half of the spore; measured 3.07 - $3.58(3.33 \pm 0.12) \mu \mathrm{m}$ in length and $1.68-2.42(2.09 \pm 0.18) \mu \mathrm{m}$ in width ( $=30)$ (Fig. 1 b-h). Polar filaments formed 4 coils, and measured 23.22 - $36.22(29.61 \pm 4.75) \mu \mathrm{m}$ in length, when extruded (Fig. $1 \mathrm{~d}, \mathrm{~g})$. Sporoplasm homogenous, binucleate, with a rudimentary nucleus and a vacuole, and occupied the whole extracapsular space behind the polar capsules (Fig. $1 \mathrm{c}, \mathrm{h}$ ). Deformed spores with caudal appendages were observed infrequently (Fig. 1e).

\section{Taxonomic summary}

\section{Phylum: Cnidaria}

Unranked Subphylum: Myxozoa Grassé, 1970

Class: Myxosporea Bütschli, 1881

Order: Bivalvulidae Shulman, 1959

Family: Myxobolidae Thelohan, 1892

Genus: Myxobolus Bütschli, 1882

Species: Myxobolus cochinensis n. sp.

Host:Planiliza macrolepis (Mugilidae) Smith, 1846

Type locality: Cochin backwaters, Southwest coast of India $\left(9.9312^{\circ} \mathrm{N}, 76.2673^{\circ} \mathrm{E}\right)$

Site/Organ: Gill filaments

Prevalence: 3 of 222 P. macrolepis were infected (1.3\%)

Etymology: Named after the locality from where the parasite was recovered.

\section{Type material}

Voucher specimen (air-dried, Giemsa-stained myxospores) deposited in the parasite collections of the Marine Biodiversity Museum, Central Marine Fisheries Research Institute, India (Accession number: CD. 1. 1. 1. 2) and partial sequences of $18 S$ SSU rDNA gene deposited in NCBI GenBank (Accession numbers: MT305662, MT305663 and MT305666).

\section{Remarks}

Morphological features place the present myxosporean under the genus Myxobolus. Among the species of Myxobolus possessing spores with rounded anterior and slightly narrow posterior ends, two equal polar capsules and without sutural ornamentation, the present species exhibit close similarities with M. discrepans infecting Ictiobus bubalis (Rice et al. 1943), M. stomum infecting Plectorhincus gaterinus (Ali et al. 2003), M. cycloides and M. mulleri infecting Leuciscus cephalus (Molnár et al. 2006), M. pethericii infecting Ctenopoma petherici (Fomena et al. 2007), M. agolus and M. clarii infecting Oreochromis niloticus (Mohammed et al. 2012) and M. nigerae infecting Schizothorax niger (Dar et al. 2016). A comparison of the above eight species with the present myxosporean (Table 1) indicate that, except M. nigerae, all the above species differ from the present species in having larger myxospores and polar capsules. Though $M$. nigerae closely resembles the present species in spore dimensions, it differs in the width of the polar capsule, number of polar filament coils and infects a fresh water fish host. The present species differs from all the above species except $M$. pethericii in the number of polar filament coils. Further, M. discrepans, M. cycloides, and M. mulleri can be differentiated based on the presence of intercapsular process, while $M$. stomum and $M$. cycloides differs in the site of infection. Among the compared species, the present myxosporean infect $P$. macrolepis which belong to family Mugilidae, and except $M$. nigerae, all the compared species have been reported from different geographic locations. Though $M$. ramadus, $M$. cerveirensis, $M$. episquamalis and $M$. exiguus comes close to the current species in BLASTN analysis, they exhibit strong morphological and morphometric differences with the present species. Considering the differences in morphology and morphometry the present myxosporean is treated as a new species, and named Myxobolus cochinensis $\mathrm{n}$. sp.

\section{Histology}


In histological preparations, the elongated, intrafilamental-epithelial (FE) type plasmodia were lodged within the body of the gill filament. Infected gill filament appeared slightly dilated/swollen and deformed (Fig. 2a). The cyst wall was moderately thick and enclosed mature and immature spores (Fig. 2b). Pathological changes included lamellar hypertrophy and total destruction of infected gill lamellae. Compression of lamellae on the adjacent gill filaments was also noticed. (Fig. 2c).

\section{Molecular analysis}

Partial 18S SSU rDNA sequences ( 1902bp, 1955bp and 1908bp) of the three isolates of the present myxosporean were identical (Accession numbers: MT305662, MT305663 and MT305666) and exhibited $0.1 \%$ to $0.2 \%$ divergence (Table 2 ). In sequence similarity analysis using BLASTn tool, the sequences showed a highest identity of $89.77 \%$ with $M$. ramadus (MK203074) infecting the gill lamellae of Chelon ramada, followed by $87.76 \%$ with $M$. cerveirensis (MK203079) parasitizing the intestine of Chelon ramada, $87.42 \%$ with $M$. episquamalis (JF810537) infecting the scales of Mugil cephalus and $86.99 \%$ with M. exiguus (MH236070) infecting the peritoneum of Chelon ramada. In genetic distance analysis using P-distance model, isolates of the present myxosporean showed a divergence of $11.9 \%$ to $12.1 \%$ with $M$. ramadus, the closest myxosporean sequence in BLASTN analysis. Other compared sequences exhibited still lower molecular identities and higher divergence values, suggesting the molecular uniqueness of the present species.

\section{Phylogenetic analysis}

In phylogenetic analysis genus Myxobolus appeared polyphyletic. Isolates of $M$. cochinensis n. sp. occupied an independent position within the Myxobolus clade with high nodal support in both $\mathrm{BI}$ and $\mathrm{ML}$ analyses (1/100). In $\mathrm{ML}$ tree, $M$. ramadus appeared as sister taxa to the present parasite with a bootstrap value of 0.93/99 (Fig. 2).

\section{Discussion}

The present study describes a new species of myxosporean, M. cochinensis $\mathrm{n}$. $\mathrm{sp}$. infecting the largescale mullet, $P$. macrolepis from Cochin backwaters. Although myxospore morphology and morphometry constitute the foundation for myxosporean systematics, recent advances in molecular systematics using 18S SSU rDNA based phylogenetic inferences have greatly improved the perception of myxosporeans (Ye et al. 2014). Moreover, molecular studies allow the separation of morphologically indistinguishable species (Cech et al. 2012), thereby resolving the taxonomic ambiguities existing in many species. Members of the genus Myxobolus are generally known to exhibit high levels of tissue and host specificities and hence these features are also considered important in the taxonomy of the group (Guo et al. 2016).

Molecular analysis of $18 \mathrm{~S} \mathrm{SSU}$ rDNA of the three isolates of $M$. cochinensis $\mathrm{n}$. sp. revealed a divergence value of 0.1 to 0.2 , demonstrating their conspecific nature. Sequences of M. cochinensis n. sp. exhibited a molecular divergence of $11.9 \%$ to $12.1 \%$ with $M$. ramadus, the closest reference sequence in BLASTN analysis, suggesting its molecular uniqueness (Table 2). Fiala et al. (2015) have remarked that Myxobolus clade appears as the largest lineage within the myxozoan phylogenetic tree and exhibits a polyphyletic origin. In the present study also, genus Myxobolus exhibited a polyphyletic origin in both $\mathrm{ML}$ and $\mathrm{BI}$ tree topologies with $M$. ramadus, appearing as a sister taxa. According to Fiala (2006), interspecific SSU variation in the Myxosporea is greater than 2\%, while Ferguson et al. (2008) observed that in some genera like Myxobolus, it can be as low as $0.2 \%$. In the present study, phylogenetic trees constructed with ML and BI methods were identical, with the isolates of $M$. cochinensis $n$. sp. forming a distinct cluster with high bootstrap value, indicating their identity as a unique species.

Mullets appear to be one of the preferred hosts for myxosporeans, especially those belonging to the genus Myxobolus (Yurakhno \& Ovcharenko 2014). The prevalence observed for M. cochinensis $\mathrm{n}$. sp. in the present study was relatively low (1.3\%). The prevalence reported for Myxobolus infections in fishes varied from $2.31 \%$ to $70 \%$ and $4.12 \%$ to $80 \%$ in freshwater and marine habitats respectively (Padma Dorothy \& Kalavati 1992; Awakura et al.1995; Zhang et al. 2010; Salman et al. 2017). In mullets, the prevalence of Myxobolus infection varied from $4.5 \%$ to $60 \%$ and $1.8 \%$ to $80 \%$ in freshwater and marine/brackishwater habitats respectively (Bahri et al. 1996; Ovcharenko et al. 2017; Cardim et al. 2018; Rocha et al. 2019). Variations in prevalence could be ascribed to factors including availability of definitive and intermediate hosts, climatic and environmental conditions and nutrient levels in their respective habitats (Yokoyama \& Fukuda 2001).

Histopathology revealed that the infected gill filament appeared slightly swollen and deformed with compression/destruction of gill lamellae. These alterations in the gill surface architecture can reduce the gaseous exchange capacity of the gills. Similar observations were made by Cardim et al. (2018) in M. bragantinus infecting the gills of M. rubrioculus, and by Ahmed et al. (2019) in M. himalayaensis from the gills of S. richardsonii. Kaur \& Katoch (2016) revealed that cysts of Myxobolus in the secondary gill lamellae induce hypertrophy and inflammation of secondary lamellae, leading to asphyxia in the host. Dar et al. (2017) reported inactivation of infected gill lamellae due to intra-lamellar vascular (LV3) type infection causing necrosis, hypertrophy and hyperplasia of the calciform cells. Marcotegui \& Martorelli (2017) observed that cysts of $M$. saladensis infecting the gill epithelium of $M$. liza may interfere with the respiratory function of the host. 
Considering the striking morphological, morphometric, molecular and phylogenetic differences with existing species of myxosporeans, together with differences in host and geographical locations, the present species of Myxobolus recovered from P. macrolepis is viewed as a new species and the name Myxobolus cochinensis $\mathrm{n}$. sp. is proposed.

\section{Declarations}

\section{Acknowledgements}

The authors wish to thank the Director, Central Marine Fisheries Research Institute, Cochin, and the Indian Council of Agricultural Research, New Delhi, for providing necessary facilities for undertaking this work. The present study was supported by the Council of Scientific \& Industrial Research, New Delhi, through a Junior Research Fellowship for the first author (No. 09/1135(0008)/2017-EMR-I).

Author's contribution: The study was designed and guided by N.K. Sanil and P. Vijayagopal. Mary Soniya Correya carried out the study in detail. The manuscript was written by all the authors.

Compliance with ethical standards: All applicable institutional, national and international guidelines for the care and use of animals were followed in the present study.

Conflict of interest: The authors declare that that there is no conflict of interest between them.

\section{References}

Abidi R, Fariya N, Irshan M, Chauhan UK (2015) A new species of myxozoan parasite, Myxobolus lucknowii sp. nov. in kidney of Clarias batrachus Linn. from river Gomti at Lucknow. Trends Parasitol Res 4:2319-3158

Ahmed I, Ahmad I, Dar SA, Awas M, Kaur H, Ganai BA, Shah BA (2019) Myxobolus himalayaensis sp. nov. (Cnidaria: Myxozoa) parasiting Schizothorax richardsonii (Cyprinidae: Schizothoracinae) from River Poonch in North West Himalaya, India. Aquaculture Reports. 14:100192

Ali MA, Abdel-Baki AS, Sakran T, Entzeroth R, Abdel-Ghaffar F (2003) Light and electron microscopic studies of Myxobolus stomum n. sp. (Myxosporea: Myxobolidae) infecting the blackspotted grunt, Plectorhynicus gaterinus (Forsskal, 1775) in the Red Sea, Egypt. Parasitol Res 91: 390-397

Awakura T, Nagasawa K, Urawa S (1995) Occurrence of Myxobolus arcticus and M. neurobius (Myxozoa: Myxosporea) in Masu Salmon Oncorhynchus masou from Northern Japan. Sci Reports of the Hokkaido Salmon Hatchery 49: 35-40

Bahri S, Marques A (1996) Myxosporean parasities of the genus Myxobolus from Mugli cephalus in Ichkeul lagoon, Tunisia: description of two new species. Dis. Aquat. Org. 27: 115-122

Barta JR, Martin DS, Liberator PA, Dashkevicz M, Anderson JW, et al. (1997) Phylogenetic relationships among eight Eimeria species infecting domestic fowl inferred using complete small subunit ribosomal DNA sequences. J Parasitol 83: 262-271

Cardim J, Silva D, Hamoy I, Matos E, Abrunhosa F (2018) Myxobolus bragantinus n.sp.(Cnidaria: Myxosporea) from the gill filaments of the red eye mullet, Mugil rubrioculus (Mugiliformes: Mugilidae), on the eastern Amazon coast. Zootaxa. 4482:177-187

Cech G, Molnar K, Szekely C (2012) Molecular genetic studies on morphologically distinguishable Myxobolus spp. infecting cyprinid fishes, with the description of three new species, M. alvarezae sp. nov., M. sitjae sp. nov. and M. eirasianus sp. nov. Acta Parasitol. 57:354-366

Chandran A, Sanil NK, Zacharia PU (2019) Ortholinea scatophagi (Myxosporea: Ortholineidae), a novel myxosporean infecting the spotted scat, Scatophagus argus (Linnaeus 1766) from southwest coast of India. Parasitol Int. 75:102020

Dar SA, Kaur H, Chishti MZ (2016) Morphological and histopathological description of Myxobolus nigeraen. sp. infecting gills of a cold water native cyprinid fish, Schizothorax niger from Wullar Lake (India). Species. 17:109-118

Dar SA, Kaur H, Chishti MZ (2017) First record of Myxozoan parasites from fresh water fishes of Jammu and Kashmir and their pathogenicity. Micro. Pathol. 105:138-144

Diamant A, Whipps CM, Kent ML (2004) A new species of Sphaeromyxa (Myxosporea : Sphaeromyxina : Sphaeromyxidae) in devil firefish, Pterois miles (Scorpaenidae), from the northern Red Sea: Morphology, ultrastructure, and phylogeny. J Parasitol 90: 1434-1442 
Eiras JC, D'Souza J (2004) Myxobolus goensis n. sp. (Myxozoa, Myxosporea, Myxobolidae), a parasite of the gills of Mugil cephalus (Osteichthyes, Mugilidae) from Goa, India. Parasite. 11:243-248

Eiras JC, Zhang J, Molnár K (2014) Synopsis of the species of Myxobolus Bütschli, 1882 (Myxozoa: Myxosporea, Myxobolidae) described between 2005 and 2013. Syst Parasitol. 88:11-36

Ferguson JA, Atkinson SD, Whipps CM, Kent ML (2008) Molecular and morphological analysis of Myxobolus spp. of salmonid fishes with the description of a new Myxobolus species. J Parasitol. 94:1322- 1334

Fiala I (2006) The phylogeny of Myxosporea (Myxozoa) based on small subunit ribosomal RNA gene analysis. Int J Parasitol. 36:15211534

Fiala I, Bartošová-Sojková P, Whipps CM (2015) Classification and phylogenetics of Myxozoa. In: Okamura, B, Gruhl, A, Bartholomew J (eds.), Myxozoan evolution, Ecology and Development. Springer, Cham, 85-110

Fomena A, Lekeufack Folefack GB, Tang II C (2007) New Species of Myxobolus (Myxosporea: Myxobolidae) Parasites of Fresh Water Fishes in Cameroon (Central Africa). J Bio Sci. 7: 1171-1178

Guo Q, Zhai Y, Gu Z, Liu Y (2016) Histopathological and ultrastructural studies of Myxobolus turpisrotundus from allogynogenetic gibel carp, Carassius auratus gibelio in China. Folia Parasitol. 63:033

Haldar DP, Samal KK, Mukhopadhyay D (1996) Studies on the protozoan parasites of fishes in Orissa: eight species of Myxobolus Bütschli (Myxozoa: Bivalvulida). J. Beng. Nat. Hist. Soc. 16:3-24

Hall TA (1999) BioEdit: a user-friendly biological sequence alignment editor and analysis program for Windows 95/98/NT. Nucl Acids Symp Ser. 41: $95-98$

Hallett SL, Diamant A (2001) Ultrastructure and small-subunit ribosomal DNA sequence of Henneguya lesteri n. sp (Myxosporea), a parasite of sand whiting Sillago analis (Sillaginidae) from the coast of Queensland, Australia. Dis Aquat Organ 46: 197-212

Kaur H, Singh R (2012) A synopsis of the species Myxobolus Bütschli, 1882 (Myxozoa: Bivalvulida) parasitizing Indian fishes and a revised key to myxosporean genera. Syst Parasitol. 81:17-37

Kaur H, Katoch A (2016) Prevalence, site and tissue preference of myxozoan parasites infecting gills of cultured fish in Punjab (India). Diseases of Aquatic Organisms, 118, 129-137

Kumar S, Stecher G, Tamura K (2016) MEGA7: molecular evolutionary genetics analysis version 7.0 for bigger datasets. Mol Biol Evol. 33: $1870-1874$

Lom J, Arthur JR (1989) A guideline for the preparation of species descriptions in Myxosporea. J Fish Dis. 12:151-156

Lom J, Dyková I (1992) Protozoan Parasites of Fishes. In: Developments in Aquaculture and Fisheries Science Elsevier, New York, pp 315 p

Lom J, Dykova I (2006) Myxozoan genera: definition and notes on taxonomy, life-cycle terminology and pathogenic species. Folia Parasitol. 53: 1-36

Luther G (1973) The grey mullet fishery resources of India. In: Proceedings of the symposium on living resources of the seas around India. Mandapam Camp.

Marcotegui P, Martorelli S (2017) Myxobolus saladensis sp. nov., a new species of gill parasite of Mugil liza (Osteichthyes, Mugilidae) from Samborombón Bay, Buenos Aires, Argentina. Iheringia Ser Zool. 107: 1-5

Miller LT, Adlard RD (2012) Brain infecting kudoids of Australia's coral reefs, including a description of Kudoa lemniscatin. sp. (Myxosporea: Kudoidae) from Lutjanus lemniscatus (Perciformes: Lutjanidae) off Ningaloo Reef, Western Australia. Parasitol Int. 61:333- 342

Mohammed NI, Rabie SA, Hussein ANA, Hussein NM (2012) Infestation of Oreochromis niloticus and Tilapia zilli fresh-water fishes with myxosporean parasites, Qena Province, Egypt. Egypt. Acad. J. Biolog. Sci. 4:235-246

Molnár K, Marton S, Eszterbauer E, Székely C (2006) Comparative morphological and molecular studies on Myxobolus spp. infecting chub from the river Danube, Hungary, and description of M. muellericus sp. n. Dis Aquat Organ. 73:49-61

Page $7 / 12$ 
Narasimhamurti CC (1970) Myxosoma intestinalis n. sp. (Protozoa, Myxosporidia) from the gut epithelium of the estuarine fish, Mugil waigensis (Quoy \& Gaimard). Proc. Indian Acad. Sci. 81:19-27

Narasimhamurti CC, Kalavati C (1979) Myxosoma lairdin. sp., (Protozoa: Myxosporidia) parasitic in the gut of the estuarine fish, Liza macrolepis Smith. Proc. Indian. Acad. Sci. 88B:269-272

Narasimhamurti CC, Kalavati C, Saratchandra B (1980) Myxosoma microspora n. sp. (Myxosporidia : Protozoa) parasitic in the gills of Mugil cephalus L. J. Fish. Bioi. U.K. $16: 345-348$

Ovcharenko M, Dezfuli BS, Castaldelli G, Lanzoni M, Giari L (2017) Histological and ultrastructural study of Myxobolus mugchelo (Parenzan, 1966) with initial histopathology survey of the Liza ramada host intestine. Parasitol Res 116:1713-1721

Özer A, Gürkanli CT, Özkan H, Acar G, Ciftci Y, Yurakhno V (2016) Molecular characterization and morphological aspects of Myxobolus parvus (Myxozoa) from Liza saliens (Mugilidae) off the Turkish Black Sea coasts. Parasitol Res. 115:3513-3518

Padma Dorothy K, Kalavati C (1992) Two new myxosporean parasites of the mullet, Liza macrolepis (Smith), Uttar Pradesh. J. Zool. 12:1519

Rambaut A (2008) FigTree v1.1.1: Tree figure drawing tool http://tree.bio.ed.ac.uk/software/figtree/

Rice, Verne J, Jahn, Theodore L (1943) Myxoporidian Parasites from the Gills of Some Fishes of the Okoboji Region Proceedings of the lowa Academy of Science. 50:313-321

Rocha S, Casal G, Alves Â, Antunes C, Rodrigues P, Azevedo C (2019) Myxozoan biodiversity in mullets (Teleostei, Mugilidae) unravels hyperdiversification of Myxobolus (Cnidaria, Myxosporea). Parasitol Res. 118:3279-3305

Rocha S, Azevedo C, Oliveira E, Alves Â, Antunes C, Rodrigues P, Casal G (2019a) Phylogeny and comprehensive revision of mugiliform infecting myxobolids (Myxozoa, Myxobolidae), with the morphological and molecular redescription of the cryptic species Myxobolus exiguus. Parasitol. 146:479-496

Ronquist F, Huelsenbeck JP (2003) MrBayes 3: Bayesian phylogenetic inference under mixed models. Bioinform 19:1572-1574

Salman HM, Dayoub Al, Merella P, Kurhaily NM (2017) First Record of Myxobolus Species (Myxosporea: Myxobolidae) in Grey Mullet Mugil cephalus (Teleostei, Mugilidae) from Syria. SSRG Int J Agri \& Envtl Sci. 4:77-82

Sarkar NK (1989) Myxobolus anili sp. nov. (Myxozoa: Myxosporea) from marine teleost fish, Rhinomugil corsula Hamilton. Proc. Zool. Soc. Calcutta, 42: 71-74

Sarkar NK (1999) Some new Myxosporidia (Myxozoa: Myxosporea) of the genera Myxobolus Butschli, 1882, Unicapsula Davis, 1942, Kudoa Meglitsch, 1947, Ortholinea Shulman, 1962 and Neoparvicapsula Gajevskaya, Kovaleva and Shulman, 1982. Proc Zool Soc Calcutta 52:3848

Wolf K, Markiw ME (1984) Biology contravenes taxonomy in the Myxozoa: New discoveries show alternation of invertebrate and vertebrate hosts. Science. 225:1449-1452

Ye LT, Li WX, Wang WW, Wu SG, Wang GT (2014) Updated morphology, histopathology and molecular phylogeny of Myxobolus hearti, cardiac myxosporea in gibel carp, Carassius gibelio (Bloch). J Fish Dis. 37:11-20

Yokoyama H, Fukuda Y (2001) Ceratomyxa seriolaen. sp. and C. buri n. sp. (Myxozoa: Myxosporea) from the gall-bladder of cultured yellowtail, Seriola quinqueradiata. Syst Parasitol 48: 125-130

Yurakhno VM, Ovcharenko MO (2014) Study of Myxosporea (Myxozoa), infecting worldwide mullets with description of a new species. Parasitol Res. 113:3661-3674

Zhang JY, Wang JG, Li AH, Gong XN (2010) Infection of Myxobolus turpisrotundus sp. n. in allogynogenetic gibel carp, Carassius auratus gibelio (Bloch), with revision of Myxobolus rotundus (s. I.) Nemeczek reported from C. auratus auratus (L.). J F Dis. 33:625-638

\section{Tables}

Table 1: Showing myxospore dimensions $(\mu \mathrm{m})$ of Myxobolus cochinensis $\mathrm{n}$. sp. with morphologically similar species 


\begin{tabular}{|c|c|c|c|c|c|c|c|c|c|}
\hline \multirow[t]{2}{*}{ Species } & \multicolumn{5}{|c|}{ Myxospore measurements } & \multirow{2}{*}{$\begin{array}{l}\text { Site of } \\
\text { infection }\end{array}$} & \multirow[t]{2}{*}{ Host } & \multirow{2}{*}{$\begin{array}{l}\text { Geographic } \\
\text { region }\end{array}$} & \multirow[t]{2}{*}{ Reference } \\
\hline & $S L$ & sW & PCL & PCW & $\mathrm{NC}$ & & & & \\
\hline $\begin{array}{l}\text { M. } \\
\text { discrepans }\end{array}$ & 15.5 & 13.9 & 5.4 & 3.9 & $\begin{array}{l}8- \\
10\end{array}$ & Gills & $\begin{array}{l}\text { Ictiobus } \\
\text { bubalis }\end{array}$ & USA & $\begin{array}{l}\text { Rice } \\
\text { etal.,1943 }\end{array}$ \\
\hline M. stomum & $\begin{array}{l}7.0-10.0 \\
(8.5)\end{array}$ & $\begin{array}{l}5.5-7.5 \\
(6.5)\end{array}$ & $\begin{array}{l}4.0-5.0 \\
(4.4)\end{array}$ & $\begin{array}{l}2.0-3.0 \\
(2.4)\end{array}$ & $5-6$ & $\begin{array}{l}\text { Oral cavity } \\
\text { muscle }\end{array}$ & $\begin{array}{l}\text { Plectorhincus } \\
\text { gaterinus }\end{array}$ & Egypt & $\begin{array}{l}\text { Ali et } \\
\text { al.,2003 }\end{array}$ \\
\hline $\begin{array}{l}\text { M. } \\
\text { cycloides }\end{array}$ & $\begin{array}{l}13-15.2 \\
(14.1)\end{array}$ & $\begin{array}{l}9.8-11.1 \\
(10.43)\end{array}$ & $\begin{array}{l}4.1-6.5 \\
(5.2)\end{array}$ & $\begin{array}{l}3.0-4.0 \\
(3.36)\end{array}$ & $6-7$ & $\begin{array}{l}\text { Swim } \\
\text { bladder }\end{array}$ & $\begin{array}{l}\text { Leuciscus } \\
\text { cephalus }\end{array}$ & Hungary & $\begin{array}{l}\text { Molnar et } \\
\text { al.,2006 }\end{array}$ \\
\hline M. mulleri & $\begin{array}{l}9.5-10.0 \\
(9.8)\end{array}$ & $\begin{array}{l}7.5-8.0 \\
(7.5)\end{array}$ & $\begin{array}{l}5.0-5.5 \\
(5.2)\end{array}$ & $\begin{array}{l}4.0-5.0 \\
(4.6)\end{array}$ & $5-6$ & Gills & $\begin{array}{l}\text { Leuciscus } \\
\text { cephalus }\end{array}$ & Hungary & $\begin{array}{l}\text { Molnar et } \\
\text { al.,2006 }\end{array}$ \\
\hline $\begin{array}{l}\text { M. } \\
\text { pethericii }\end{array}$ & $\begin{array}{l}12.0-14.0 \\
(12.6)\end{array}$ & $\begin{array}{l}6.5-7.8 \\
(7.0)\end{array}$ & $\begin{array}{l}5.0-6.0 \\
(5.3)\end{array}$ & $\begin{array}{l}1.5-2.0 \\
(1.8)\end{array}$ & $4-5$ & Gills & $\begin{array}{l}\text { Ctenopoma } \\
\text { petherici }\end{array}$ & Cameroon & $\begin{array}{l}\text { Fomena et } \\
\text { al.,2007 }\end{array}$ \\
\hline M. agolus & $10.5-11.2$ & $8.5-9.2$ & $4.8-5.5$ & $3.5-3.8$ & $\begin{array}{l}10- \\
11\end{array}$ & Gills & $\begin{array}{l}\text { Oreochromis } \\
\text { niloticus }\end{array}$ & Egypt & $\begin{array}{l}\text { Mohammed } \\
\text { et al., } 2012\end{array}$ \\
\hline M. clarii & $9.1-12.4$ & $6.8-9.7$ & $3.7-4.8$ & $2.1-3.0$ & 5 & Gills & $\begin{array}{l}\text { Oreochromis } \\
\text { niloticus }\end{array}$ & Egypt & $\begin{array}{l}\text { Mohammed } \\
\text { et al., } 2012\end{array}$ \\
\hline M. nigerae & $\begin{array}{l}6.3-6.9 \\
(6.6)\end{array}$ & $\begin{array}{l}4.8-5.2 \\
(5.0)\end{array}$ & $\begin{array}{l}3.1-3.5 \\
(3.3)\end{array}$ & $\begin{array}{l}1.5-1.7 \\
(1.6)\end{array}$ & 5 & Gills & $\begin{array}{l}\text { Schizothorax } \\
\text { niger }\end{array}$ & India & $\begin{array}{l}\text { Dar et } \\
\text { al.,2016 }\end{array}$ \\
\hline $\begin{array}{l}\text { M. } \\
\text { cochinensis } \\
\text { n. sp. }\end{array}$ & $\begin{array}{l}6.24- \\
7.02 \\
(6.63)\end{array}$ & $\begin{array}{l}5.01- \\
6.18 \\
(5.68)\end{array}$ & $\begin{array}{l}3.07- \\
3.58 \\
(3.33)\end{array}$ & $\begin{array}{l}1.68- \\
2.42 \\
(2.09)\end{array}$ & 4 & Gills & $\begin{array}{l}\text { Planiliza } \\
\text { macrolepis }\end{array}$ & India & $\begin{array}{l}\text { Present } \\
\text { study }\end{array}$ \\
\hline
\end{tabular}

(SL-spore length, SW-spore width, PCL-polar capsule length, PCW-polar capsule width, NC-no. of coils)

Table 2: Estimates of pairwise distance between the sequences of Myxobolus cochinensis $\mathrm{n}$. sp. and other closest myxosporeans available in NCBI GenBank. The genetic distance values and the number of different nucleotides are given below and above the diagonal respectively. 


\begin{tabular}{|c|c|c|c|c|c|c|c|c|c|c|c|c|c|c|c|}
\hline $\begin{array}{l}\text { Sl. } \\
\text { No. }\end{array}$ & Myxobolus Species & 1 & 2 & 3 & 4 & 5 & 6 & 7 & 8 & 9 & 10 & 11 & 12 & 13 & 14 \\
\hline 1. & $\begin{array}{l}\text { M. cochinensis } \\
\text { (MT305663) }\end{array}$ & & 1 & 2 & 218 & 218 & 178 & 231 & 254 & 236 & 258 & 261 & 245 & 257 & 277 \\
\hline 2. & $\begin{array}{l}\text { M. cochinensis } \\
\text { (MT305662) }\end{array}$ & 0.1 & & 3 & 219 & 219 & 179 & 232 & 255 & 237 & 259 & 262 & 246 & 258 & 278 \\
\hline 3. & $\begin{array}{l}\text { M. cochinensis } \\
\text { (MT305666) }\end{array}$ & 0.1 & 0.2 & & 220 & 220 & 180 & 233 & 256 & 238 & 260 & 263 & 247 & 259 & 279 \\
\hline 4. & $\begin{array}{l}\text { M. muscularis } \\
\text { (MK203075) }\end{array}$ & 15.0 & 15.1 & 15.1 & & 179 & 212 & 137 & 193 & 136 & 206 & 207 & 155 & 202 & 183 \\
\hline 5. & $\begin{array}{l}\text { M. episquamalis } \\
\text { (JF810537) }\end{array}$ & 15.0 & 15.0 & 15.1 & 12.0 & & 205 & 200 & 173 & 197 & 184 & 188 & 208 & 183 & 241 \\
\hline 6. & $\begin{array}{l}\text { M. ramadus } \\
\text { (MK203074) }\end{array}$ & 11.9 & 12.0 & 12.1 & 14.5 & 14.0 & & 229 & 234 & 237 & 242 & 244 & 241 & 239 & 281 \\
\hline 7. & $\begin{array}{l}\text { M. cerveirensis } \\
\text { (MK203079) }\end{array}$ & 16.0 & 16.1 & 16.1 & 9.0 & 13.6 & 15.8 & & 226 & 153 & 225 & 224 & 176 & 226 & 197 \\
\hline 8. & $\begin{array}{l}\text { Myxobolus sp. WSK- } \\
2013 \text { (KC733438) }\end{array}$ & 17.7 & 17.8 & 17.9 & 13.1 & 11.6 & 16.2 & 15.5 & & 206 & 107 & 102 & 229 & 97 & 250 \\
\hline 9. & $\begin{array}{l}\text { M. exiguus } \\
\text { (MH236070) }\end{array}$ & 16.4 & 16.5 & 16.5 & 8.9 & 13.3 & 16.4 & 10.1 & 14.0 & & 213 & 213 & 110 & 211 & 47 \\
\hline 10. & $\begin{array}{l}\text { M. } \\
\text { galaicoportucalensis } \\
\text { (MC203084) }\end{array}$ & 18.1 & 18.1 & 18.2 & 14.0 & 12.4 & 16.8 & 15.5 & 6.9 & 14.6 & & 39 & 239 & 99 & 257 \\
\hline 11. & $\begin{array}{l}\text { M. mugiliensis } \\
\text { (MK203082) }\end{array}$ & 18.3 & 18.4 & 18.5 & 14.1 & 12.7 & 17.0 & 15.4 & 6.6 & 14.6 & 2.4 & & 241 & 90 & 256 \\
\hline 12. & $\begin{array}{l}\text { M. } \\
\text { pharyngobranchialis } \\
\text { (MK203073) }\end{array}$ & 17.1 & 17.2 & 17.2 & 10.2 & 14.2 & 16.8 & 11.7 & 15.8 & 7.1 & 16.6 & 16.7 & & 233 & 150 \\
\hline 13. & $\begin{array}{l}\text { M. vesicularis } \\
\text { (MK203085) }\end{array}$ & 18.0 & 18.1 & 18.1 & 13.7 & 12.3 & 16.6 & 15.5 & 6.3 & 14.4 & 6.4 & 5.8 & 16.1 & & 257 \\
\hline 14. & $\begin{array}{l}\text { Myxobolus sp. k AC- } \\
2020 \text { (MT437045) }\end{array}$ & 19.7 & 19.8 & 19.9 & 12.3 & 16.7 & 20.0 & 13.3 & 17.4 & 3.0 & 18.0 & 18.0 & 9.9 & 18.1 & \\
\hline
\end{tabular}

Figures 

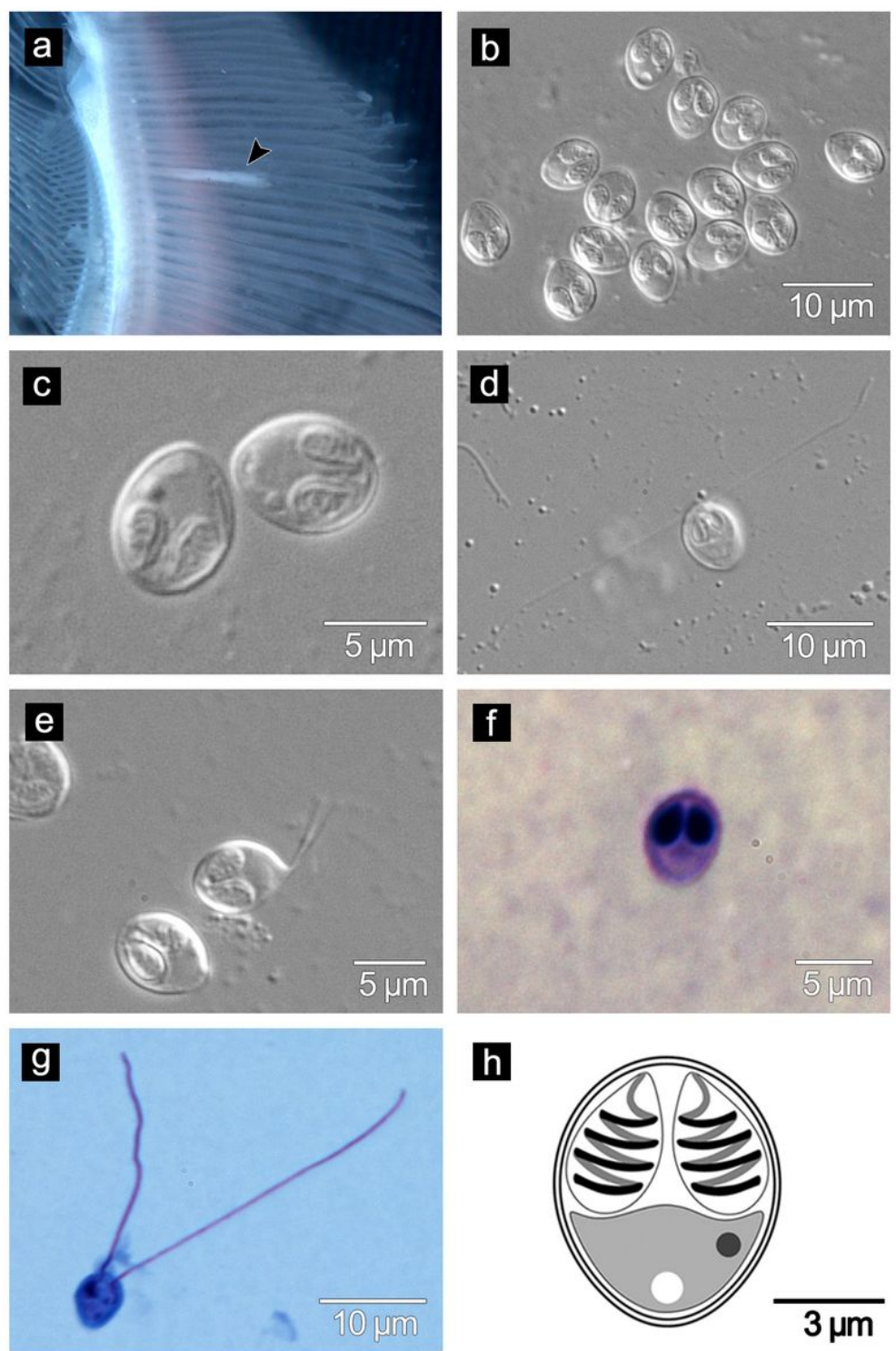

\section{Figure 1}

M. cochinensis n. sp. a) plasmodium on gill filaments; b) frontal view of myxospores; c) enlarged view of myxospores; d) myxospore showing extruded polar filaments; e) abnormal myxospore with caudal appendages; f) Giemsa-stained myxospore; g) Giemsa-stained myxospore with extruded polar filament; h) line drawing of myxospore.
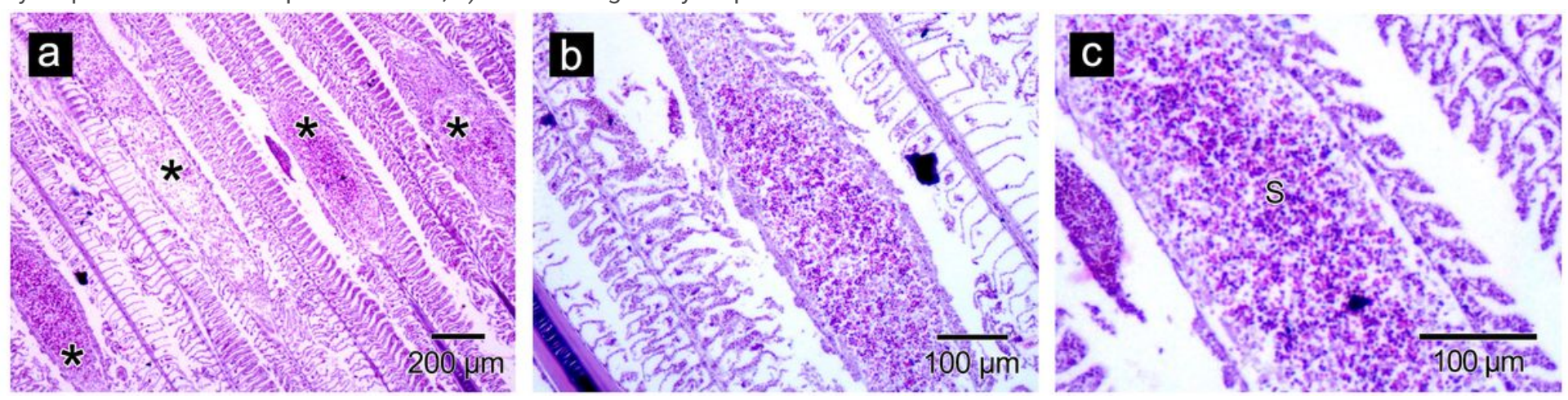

\section{Figure 2}

Histological changes caused by M. cochinensis $n$. sp. a) plasmodia on gill filaments (*); b) enlarged view showing cyst wall; c) lamellar hypertrophy and destruction of gill lamellae, S-spores. 


\section{Image not available with this version}

\section{Figure 3}

Consensus phylogenetic tree showing the evolutionary relationship of M. cochinensis $\mathrm{n}$. sp. (in bold italics) with other related species of myxosporeans. Each branch tip carries species name followed by its accession number, node values are posterior probability and bootstrap for $\mathrm{BI}$ and $\mathrm{ML}$ respectively. Dashes at nodes indicate bootstrap value of $(\mathrm{ML})<50$. In histological preparations, the elongated, intrafilamental-epithelial (FE) type plasmodia were lodged within the body of the gill filament. Infected gill filament appeared slightly dilated/swollen and deformed (Fig. 2a). The cyst wall was moderately thick and enclosed mature and immature spores (Fig. 2b).

Pathological changes included lamellar hypertrophy to total destruction of infected gill lamellae. Compression of lamellae on the adjacent gill filaments was also noticed. (Fig. 2c). 